\title{
Synthesis and X-Ray Crystal Structure of $1^{\prime}, 7^{\prime}, 7^{\prime}$-Trimethylbicyclo[2.2.1]heptane[2',3'-b]-2,3-dicyanopyrazine
}

\author{
Maksim S. Filatov, ${ }^{a}$ Olga N. Trukhina, ${ }^{\text {b }}$ Svetlana V. Efimova, ${ }^{a}$ Oscar I. Koifman, ${ }^{a}$ \\ and Mikhail K. Islyaikin ${ }^{\mathrm{a}}$
}

Dedicated to Academician Irina P. Beletskaya on the occasion of her Birthday

\author{
a Research Institute of Macroheterocycles, Ivanovo State University of Chemistry and Technology, 153000 Ivanovo, Russia \\ ${ }^{\mathrm{b}}$ Universidad Autonoma de Madrid, Cantoblanco, 280409 Madrid, Spain \\ @ Corresponding authorE-mail: islyaikin@isuct.ru
}

1',7',7'-Trimethylbicyclo[2.2.1] heptane [2',3'-b]-2,3-dicyanopyrazine 1 was prepared as a mixture of stereoisomers by the reaction of $( \pm$ camphorquinone and diaminomaleonitrile in acetic acid and was characterized by mass-spectrometry, ${ }^{1} \mathrm{H},{ }^{13} \mathrm{C} N \mathrm{NR}$, IR spectroscopy and elemental analysis. Its structure was revealed by X-Ray diffraction of a single crystal grown from ethanol. Quantum chemical calculations at DFT level were carried out for the same compound. The results of theoretical study were found to be in a good agreement with crystallography data.

Keywords: Camphorquinone, diaminomaleonitrile, synthesis, structure, dicyanopyrazine.

\section{Синтез и структура 1',7',7'-триметилбицикло[2.2.1]- гептано $\left[2{ }^{\prime}, 3^{\prime}-b\right]-2,3-$ Аицианопиразина по Аанным PCA}

\author{
М. С. Филатов, ${ }^{\text {a }}$ О. Н. Трухина, ${ }^{\text {b }}$ С. В. Ефримова, ${ }^{\text {a }}$ О. И. Койфмман, ${ }^{a}$ \\ M. К. Исляйкин ${ }^{\mathrm{a}}$
}

Посвящается акаgемику Ирине Петровне Белецкой по случаю её юбилея

${ }^{\mathrm{a}}$ НИИ Макрогетероциклических соединений, Ивановский государственный химико-технологический университет, 153000 Иваново, Россия

${ }^{\mathrm{b}}$ Universidad Autonoma de Madrid, Cantoblanco, 280409 Мадрид, Испания

@E-mail: islyaikin@isuct.ru

1',7',7'-Триметилбицикло[2.2.1]гептано[2',3'-b]-2,3-дицианопиразин в виде смеси стереоизоеров получен взаимодействием (土)камфорахинона с диаминомалеонитрилом и охарактеризован данными ИК, ${ }^{1} \mathrm{H}{ }^{13} \mathrm{C}$ ЯМР спектроскопии, масс-спектрометрии, элементного анализа, а его строение подтверждено с помощью РСА.

Ключевые слова: Камфорахинон, диаминомалеонитрил, синтез, структура, дицианопиразин. 


\section{Introduction}

Macroheterocyclic compounds (Mc), being the nearest structural analogues of porphyrazine and phthalocyanine, remain objectives of an extensive study during the last decades. ${ }^{[1-6]}$ Their properties can be easily tuned by an insertion of different heterocyclic moieties. Nevertheless, pyrazinecontaining $\mathrm{Mc}$ are not numerous, despite nitrogen-rich aromatic framework, and can give rise to the new advanced functional materials with desirable properties. Unsubstituted macroheterocyclic compounds with pyrrolepyrazine fragments are known to possess low solubility in organic solvents. ${ }^{[7]}$ Herein, peripheral substitution of macrocycle with bulky groups facilitates synthesis and study of these compounds. ${ }^{[4,8]}$ In this regard, a present paper describes preparation, as well as X-Ray and quantum chemical study of $( \pm)$ 1,2-camphorquinone-derived pyrazine-containing nitriles as further precursors for synthesis of macroheterocyclic compounds.

Various substituted pyrazines were obtained by condensation of diaminomaleonitrile with 1,2-dicarbonyl compounds in acetic acid at room temperature ${ }^{[9]}$ as well as at $118{ }^{\circ} \mathrm{C}$ and $130{ }^{\circ} \mathrm{C} \cdot .^{[10]}$ 5,6-Alkyl- and 5,6-aryl substituted pyrazines and their derivatives, such as 2,3dichloroquinoxaline-6,7-carbonitrile, were obtained by condensation with diaminomaleonitrile in methanol, using acetic $^{[11]}$ or hydrochloric ${ }^{[12]}$ acids as a catalyst. Synthesis of 5,6-bis(1H-pyrrol-2-yl)pyrazine-2,3-dicarbonitrile with a $55 \%$ yield in dichloromethane, using $\mathrm{BF}_{3}$ as a catalyst, was described. ${ }^{[13]}$ Some 2,3-dicyanopyrazine derivatives ${ }^{[14,15]}$ and, in particular, 1',7',7'-trimethylbicyclo[2.2.1]heptane-[2',3'b]-2,3-dicyanopyrazine $\mathbf{1}^{[16]}$ were obtained in an alcoholic medium, using $p$-toluene sulfonic acid as the catalyst.

\section{Experimental}

Elemental analysis was performed on Flach EA 1112 instrument and IR spectra were recorded on Avatar 360 FT-IR ESP spectrophotometer. EI+MS spectra (Bruker Reflex III spectrometer), NMR spectra (Bruker AC-300 instrument) and X-Ray structure analysis (Oxford N-HELIX device, Bruker diffractometer) were carried out in Autonomous University of Madrid. Column chromatography was carried out on silica gel (Fluka, 40-200 mesh). Chemicals were purchased from Aldrich Chemical Co. and used as received without purification.
1', 7', 7'-Trimethylbicyclo[2.2.1] heptane-[2', 3'-b]-2,3dicyanopyrazine (1). A mixture of diaminomaleonitrile $3(0.2 \mathrm{~g}$; $18 \mathrm{mmol})$ and racemic mixture of camphorquinone $2(0.3 \mathrm{~g} ; 18$ mmol) was stirred in $15 \mathrm{ml}$ of glacial acetic acid for 24 hours at room temperature and then for 3 hours at $50{ }^{\circ} \mathrm{C}$. Then the solvent was removed by evaporation and product was purified by column chromatography on silica gel (eluent: dichloromethane). Dinitrile 1 was obtained as a white solid with a good yield $(0.34 \mathrm{~g}, 85 \%)$. $\mathrm{MM}=238.29$. (EI+) $m / z: 238.12[\mathrm{M}]^{+}$, calc. for $\mathrm{C}_{14} \mathrm{H}_{14} \mathrm{~N}_{4} 238.12$. ${ }^{1} \mathrm{H}$ NMR $\left(300 \mathrm{MHz}, \mathrm{CDCl}_{3}\right) \delta_{\mathrm{H}} \mathrm{ppm}: 3.14-3.15(\mathrm{~d}, 1 \mathrm{H}, \mathrm{CH}), 1.11-$ $1.35,2.09-2.18,2.29-2.44\left(\mathrm{~m}, 2 \mathrm{H} / 1 \mathrm{H} / 1 \mathrm{H}, \mathrm{CH}_{2}\right), 0.60$ (s, 3H, $\left.\mathrm{CH}_{3}\right)$, $1.11,1.36\left(\mathrm{~s}, 3 \mathrm{H} / 3 \mathrm{H}, \mathrm{C}\left(\mathrm{CH}_{3}\right)_{2}\right) \cdot{ }^{13} \mathrm{C} \mathrm{NMR}\left(\mathrm{CDCl}_{3}\right) \delta_{\mathrm{C}} \mathrm{ppm}: 9.7,18.7$, 20.4, 24.2, 31.3, 53.7, 55.4, 57.0, 114.2, 131.2, 167.1, 169.1. IR $(\mathrm{KBr}) \vee \mathrm{cm}^{-1}: 2926,2863\left(\mathrm{CH}_{3}, \mathrm{CH}_{2}\right), 2229(\mathrm{CN}), 1737,1654,1552$ $\left(\mathrm{C}_{\mathrm{ar}} \mathrm{N}\right), 1446\left(\mathrm{CH}_{2}\right), 1381(\mathrm{CH}), 1335,1130,1028,907,754,699$, 579. Elem. Anal. Found (\%): C 70.52, H 6.2, N 23.56. Calc. for $\mathrm{C}_{14} \mathrm{H}_{14} \mathrm{~N}_{4}$ (\%): C 70.57, H 5.92, N 23.51.

\section{Results and Discussion}

1 was synthesized by condensation of $( \pm) 1,2-$ camphorquinone $\mathbf{2}$ and diaminomaleonitrile $\mathbf{3}$. Compound 1 was obtained as a racemic mixture of optical isomers highly soluble in organic solvents. Its use as a starting material in a synthesis of Mcs could give compounds with a good solubility in organic solvents, analogously to the corresponding porphyrazines. ${ }^{[16]}$

However, the usage of $p$-toluenesulfonic acid as catalyst and methanol as the reaction medium produces compound $\mathbf{1}$ with a $40 \%$ yield only. ${ }^{[14]}$ We succeeded in synthesizing this compound using acetic acid as a reaction medium with yield higher than $80 \%$.

Compound 1 was characterized by MS EI massspectrometry, ${ }^{1} \mathrm{H}$ and ${ }^{13} \mathrm{C}$ NMR spectroscopy and elemental analysis.

An intensive signal at $238 \mathrm{~m} / \mathrm{z}$ that corresponds to molecular ion $[\mathrm{M}]^{+}$as well as signals of lower intensity produced by the products of fragmentation were detected in mass-spectrum of 1 (Figure S1 (Suporting Information)).

In the ${ }^{1} \mathrm{H}$ NMR spectrum of 1 (Figure S2 (SI)), singlets at $0.60,1.11,1.36 \mathrm{ppm}$ induced by protons resonance of methyl groups of camphor fragment are observed. Multiplets at the regions of 1.11-1.35, 2.09-2.18, 2.29-2.44 ppm can be assigned to protons of secondary methyl groups. Signal of 3.14-3.15 ppm corresponds to proton resonance of tertiary methyl group, that is in agreement with the date. ${ }^{[14]}$

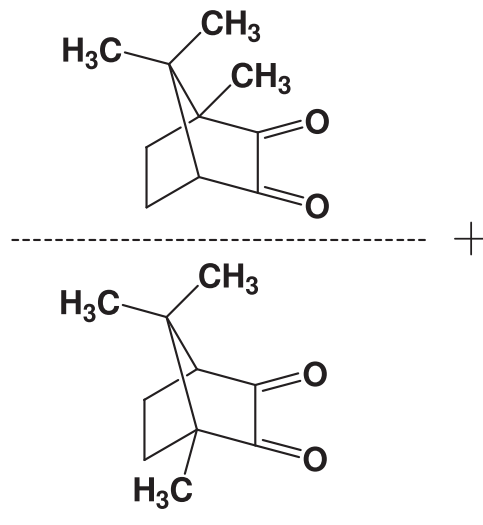

2

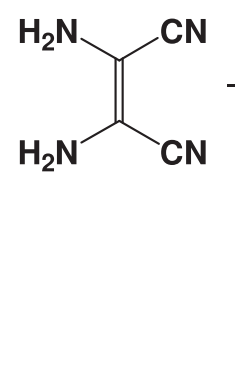

3

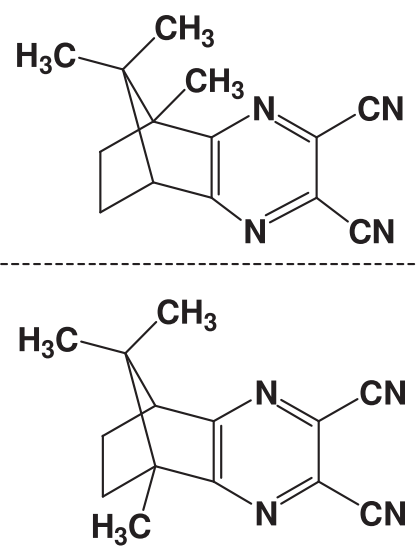

1 


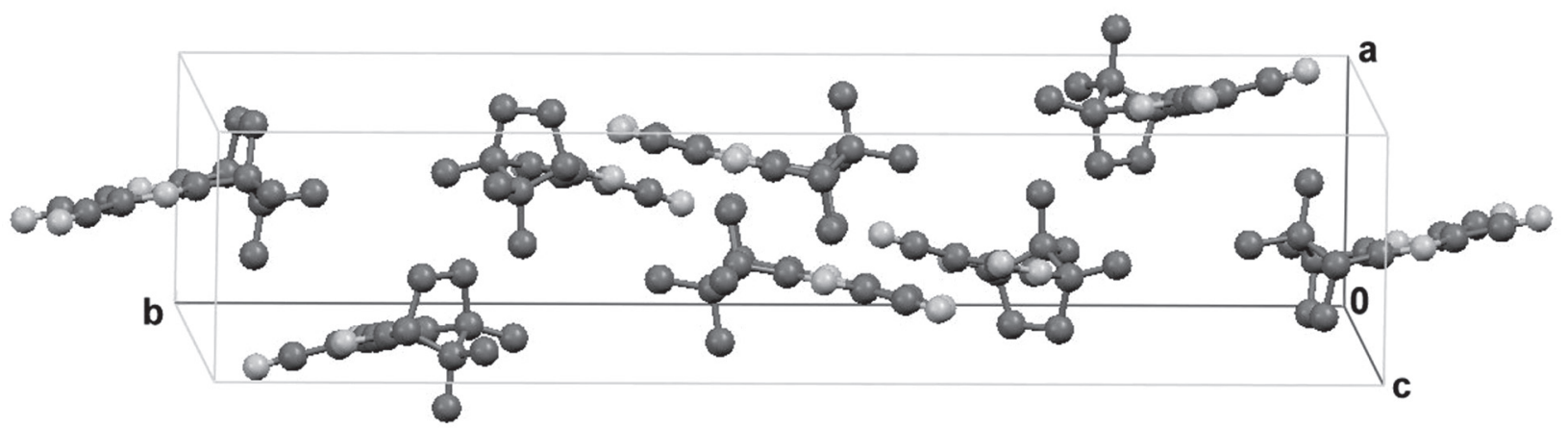

Figure 1. Crystal packing of $\mathbf{1}$, shown along $b$ axis.

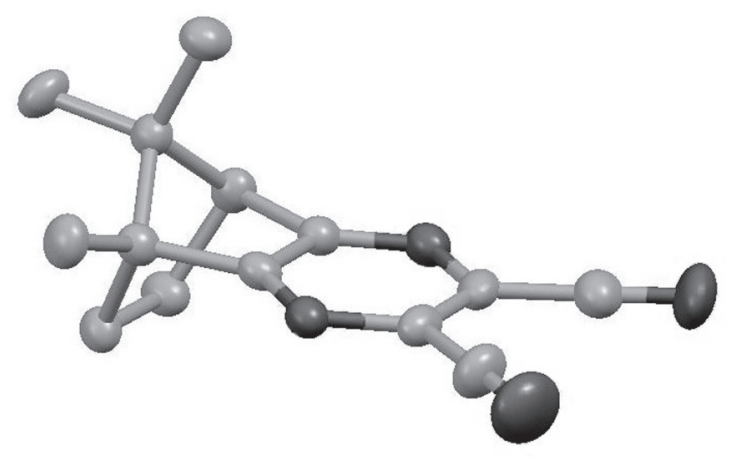

a

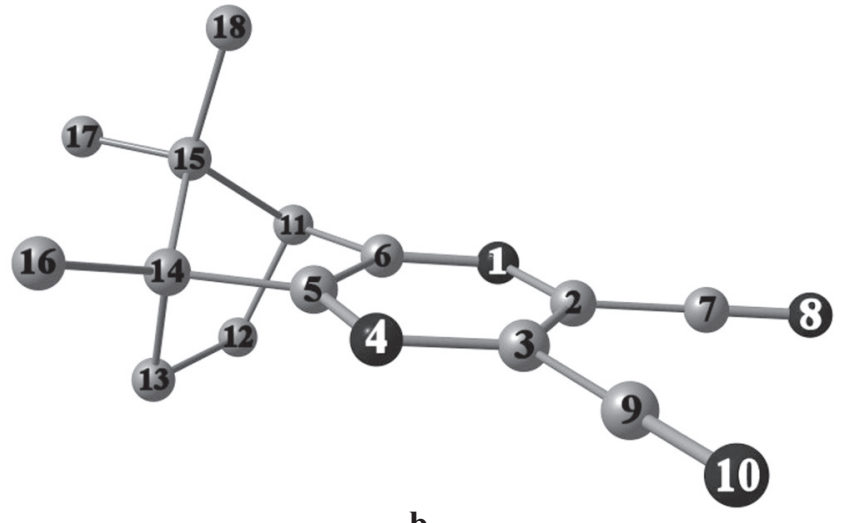

b

Figure 2. Structure of R(-)1 by X-Ray analysis (a), and optimized by DFT/B3LYP/cc-pVTZ (b). Hydrogen atoms are eliminated for clarity.

The spectrum ${ }^{13} \mathrm{C}$ NMR of $\mathbf{1}$ as well as assignment of its signals are shown in Figure S3 (SI).

Infra-red spectrum of $\mathbf{1}$ is characteristic for substituted phthalonitriles due to a strong absorption observed at 2229 $\mathrm{cm}^{-1}$, induced by stretching vibrations of $\mathrm{C} \equiv \mathrm{N}$ bonds. The bands at 2926 and $2863 \mathrm{~cm}^{-1}$ correspond to symmetric and asymmetric vibrations of $\mathrm{C}-\mathrm{H}$ bonds of camphor fragment.

Compound 1 was also characterized by X-Ray analysis. Single crystals of racemic mixture suitable for X-ray diffraction measurement were grown by slow evaporation from its ethanol solution. Monoclinic crystal with parameters $0.20 \times 0.08 \times 0.04 \mathrm{~mm}^{3}$ was analyzed at $100 \mathrm{~K}$ (cooling Oxford Cryosystem). The following parameters of the unit cell were obtained from 4326 independent reflections collected at intensity $\mathrm{R}_{\text {int }}=0.0385$ : $\mathrm{a}=7.1410(5), \mathrm{b}=33.579$ (2), $\mathrm{c}=$ 10.5417 (8) $\AA, \mathrm{V}=2517.7$ (3) $\AA^{3}, \mathrm{~d}_{\text {calc. }}=1.257 \mathrm{~g} / \mathrm{cm}^{3}$, space group $\mathrm{P} 2(1) / \mathrm{n}$. Four $\mathrm{R}(-)$-isomers and four $\mathrm{S}(+)$-isomer can be observed in the crystal unit cell. Crystal packing and structure of $\mathrm{R}(-)$ isomer are shown in Figures 1 and 2 , respectively. The crystal structure has been deposited at Cambridge Crystallographic Data Centre (CCDC 853128).

$\mathrm{X}$-Ray diffraction data of camphor fragment of compound $\mathbf{1}$ are in a good agreement with those of camphorquinone reported in literature. ${ }^{[17]}$ Herein, a deviation of bond lengths for asymmetric $\mathrm{C} 14$ and the neighbor atoms C5, C13, $\mathrm{C} 15, \mathrm{C} 16$ (atoms numeration is given in Figure $2 \mathrm{~b}$ ) was found to be only $0.016 \AA$. On going from 1 to camphorquinone, there is an insignificant increase in the values of angles (C14-C5C6, C11-C6-C5, C12-C13-C14 and C11-C12-C13 of 1-2 ${ }^{\circ}$. The maximal deviation (near $1^{\circ}$ ) was only observed for angles
Table 1. Experimental and calculated bond lengths $(\AA)$ and some bond angles $\left(^{\circ}\right)$ of $\mathbf{1}(\mathrm{R}(-))$ (Figure 2).

\begin{tabular}{ccc}
\hline Bonds, angles & X-Ray & cc-pVTZ \\
\hline N1-C2 & 1.366 & 1.353 \\
C2-C3 & 1.388 & 1.401 \\
C3-N4 & 1.365 & 1.353 \\
N4-C5 & 1.315 & 1.311 \\
C5-C6 & 1.430 & 1.416 \\
N1-C6 & 1.311 & 1.311 \\
C2-C7 & 1.451 & 1.433 \\
C3-C9 & 1.440 & 1.433 \\
C7-N8 & 1.144 & 1.152 \\
C9-N10 & 1,149 & 1.152 \\
C6-C11 & 1.503 & 1.499 \\
C11-C12 & 1.557 & 1.561 \\
C12-C13 & 1.539 & 1.554 \\
C13-C14 & 1.564 & 1.569 \\
C5-C14 & 1.495 & 1.509 \\
C14-C16 & 1.504 & 1.514 \\
C14-C15 & 1.580 & 1.588 \\
C11-C15 & 1.560 & 1.569 \\
C15-C17 & 1.522 & 1.531 \\
C15-C18 & 1.525 & 1.535 \\
C3-C2-C7 & 120.670 & 121.150 \\
C2-C3-C9 & 121.260 & 121.140 \\
C15-C14-C16 & 119.280 & 119.160 \\
C5-C14-C16 & 116.160 & 116.360 \\
C13-C14-C16 & 115.150 & 115.230 \\
\hline
\end{tabular}


formed by the asymmetric carbon atom $\mathrm{C} 14$. Hence, the formation of pyrazine ring by interaction of camphorquinone with diaminomaleonitrile produces a very low influence on geometry of the camphorquinone fragment.

Quantum-chemical calculations at the DFT level ${ }^{[18]}$ for $R(-)$ - and $S(+)$-isomer of 1 were carried out with the aim to compare geometric characteristics of molecules in a solid and an isolated states. Calculations of the second derivatives proved that optimized configurations correspond to the minima on potential energy surfaces. Resume data of X-Ray diffraction analysis and quantum-chemical calculations of $R(-)$-isomer of $\mathbf{1}$ are given in Table 1 for comparison. The geometrical parameters of $\mathbf{1}$, revealed by X-Ray analysis were found to be in a good agreement with those derived from theoretical calculations.

\section{Conclusions}

In a conclusion, an improved method of the synthesis of 1',7',7'-trimethylbicyclo[2.2.1] heptane[2',3'-b]-2,3-dicyanopyrazine 1 by interaction of racemic mixture of camphorquinone with diaminomaleonitrile in acetic acid was developed. Structure of the compound 1 was established by X-Ray analysis. The experimental data were found to be in a good agreement with quantum-chemical calculations.

Acknowledgement. This work was developed by financial support from Russian Foundation of Basic Research (12-0300364-a).

\section{References}

1. Islyaikin M.K., Danilova E.A., Romanenko Yu.V., Khelevina O.G., Lomova T.N. In: Chemical Processes with Participation of Biological and Related Compounds [Lomova T.N., Zaikov G.E., Eds.] BRILL, Leiden-Boston, 2008, p. 219.

2. Islyaikin M.K., Danilova E.A. Russ. Chem. Bull., Int. Ed. 2007, 56, 689 .
3. de la Torre G., Vazquez P., Aguillo-Lopez F., Torres T. Chem. Rev. 2004, 104, 3723.

4. Stryapan M.G., Efimova S.V., Koifman O.I., Islyaikin M.K. Macroheterocycles 2010, 3, 38.

5. Trukhina O.N., Rodríguez-Morgade M.S., Wolfrum S., Caballero E., Snejko N., Danilova E.A., Gutiérrez-Puebla E., Islyaikin M.K., Guldi D.M., Torres T. J. Am. Chem. Soc. 2010, 132, 12991-12999.

6. Trukhina O.N., Zhabanov Yu.A., Krasnov A.V., Danilova E.A., Islyaikin M.K. J. Porphyrins Phthalocyanines 2011, 15, 12871291.

7. Kulikov M.A., Vorobiev J.G., Berezin G.R., Stepanenko V.A. Zh. Obshch. Khim. 2004, 74, 1031 (in Russ.).

8. Danilova E.A., Islyaikin M.K. In: Uspekhi Khimii Porfirinov [Advances in Porphyrin Chemistry] Vol. 4 (Golubchikov O.A., Ed.) St. Petersburg: NII Khimii SPbGU. 2004, 356 (in Russ.).

9. Mitzel F., Fitzgerald S., Beeby A., Faust R. Chem. Eur. J. 2003, 9, 1233.

10. Rothkopf H.W., Wohrle D., Muller R. Chem. Ber. 1975, 108, 875.

11. Jaung J., Matsuoka M., Fukunishi K. J. Chem. Res. 1998, 284285.

12. Zimcik P., Novakova V., Miletin M., Kopecky K. Macroheterocycles 2008, 1, 21-29.

13. Rodriguez-Morqade M.S., Dan Pantos G., Caballero E., Sessler J.L., Torres T. Macroheterocycles 2008, 1, 40-43.

14. Jang Ch.K., Kim S.H., Jaung J.J. J. Porphyrins Phthalocyanines 2010, 14, 531

15. Jang Ch.K., Kim S.H., Lee D.K., Jaung J.J. Bull. Korean Chem. Soc. 2008, 29, 1665.

16. Jang Ch.K., Byun S.H., Kim S.H., Lee D.K., Jaung J.J. J. Porphyrins Phthalocyanines 2009, 13, 794.

17. Tahir M.I.M., Rees N.H., Heyes S.J., Cowley A.R., Prout K Chitality 2008, 20, 863.

18. Quantum-chemical calculations of the compound $\mathbf{1}$ were performed by DFT/B3LYP/cc-pVTZ method, using the software package PC GAMESS v.7.1.E1 (Granovsky A., http:// classic.chem.msu.su/gran/gamess/index.html). ChemCraft (Zhurko G.A., www.chemcraftprog.com) was applied for preparation of input data file, as well as for processing and visualization of the computed results.

Received 27.11.2012 Accepted 02.02.2013 